\title{
Primary intracranial basaloid squamous cell carcinoma: an enigma
}

\section{Pierwotny śródzzaszkowy bazaloidalny rak płaskonabłonkowy}

\author{
Supriya Mallick', Ahitagni Biswas', Narender Kumar², Mehar Chand Sharma², Rakesh Kumar ${ }^{3}$, Rama Mohan Reddy ${ }^{3}$, Pramod Kumar Julka', \\ Goura Kishore Rath'
}

\author{
1Department of Radiotherapy \& Oncology, All India Institute of Medical Sciences, New Delhi, India \\ 2Department of Pathology, All India Institute of Medical Sciences, New Delhi, India \\ ${ }^{3}$ Department of Nuclear Medicine, All India Institute of Medical Sciences, New Delhi, India
}

Neurologia i Neurochirurgia Polska 2012; 46, 5: 489-495

DOI: 10.5114/ninp.2012.31361

\begin{abstract}
Primary intracranial squamous cell carcinoma is extremely rare, with most cases arising from malignant transformation of dysembryogenetic lesions such as epidermoid and dermoid cysts. Intracranial squamous cell neoplasm arising de novo is even rarer and has been reported in only four patients to date. We herein describe a case of primary intracranial squamous cell carcinoma arising de novo in the right frontal lobe in a 35-year-old woman treated with a combination of surgery and postoperative conformal radiation. We have also shed light on the biology and the therapeutic options of this enigmatic tumour.
\end{abstract}

Key words: squamous cell carcinoma, intracranial, basaloid.

\section{Introduction}

Primary intracranial squamous cell carcinoma (PISCC) arising de novo is a rarity and has been described in only four patients in the available literature. We have brought into focus the biology and treatment options of this rare tumour by citing a case of PISCC arising de novo in the right frontal lobe in a 35-year-old woman treated successfully with a combination of sur gery and postoperative conformal radiation.

\section{Streszczenie}

Pierwotny śródczaszkowy rak płaskonabłonkowy jest wyjątkową rzadkością i w większości przypadków rozwija się w wyniku zezłośliwienia zmian o charakterze dysembriogenetycznym, np. torbieli naskórkowej lub skórzastej. Śródczaszkowy rak płaskonabłonkowy powstały de novo jest jeszcze rzadszy - dotąd opisano 4 takie przypadki.

W niniejszej pracy przedstawiono przypadek nowotworu powstałego de novo w prawym płacie czołowym u 35-letniej chorej, którą z tego powodu poddano leczeniu chirurgicznemu i pooperacyjnej radioterapii konformalnej. Podano również informacje na temat biologii i możliwości leczenia tego zagadkowego guza.

Słowa kluczowe: rak płaskonabłonkowy, śródczaszkowy, bazaloidalny.

\section{Case report}

A 35-year-old woman presented to our clinic with a history of recurrent headache, vomiting and focal seizures for the last two months. She also complained of dimness of vision in the left eye for the same duration. On clinical examination, higher mental function was found to be normal. Visual acuity in both eyes was noted to be 6/9. Fundoscopy revealed bilateral early papilloedema. There were no features of cranial nerve

Correspondence address: Ahitagni Biswas, MD, Department of Radiotherapy \& Oncology, All India Institute of Medical Sciences, New Delhi, India, phone: +91-9013590854,e-mail:dr_ahitagni@yahoo.co.in

Received: 19.06.2011; accepted: 25.01.2012 
palsy or sensorimotor deficit. Contrast-enhanced computed tomography (CT) of the brain showed a lesion in the right anterior frontal lobe, $4.8 \times 4.2 \mathrm{~cm}$ in size, with perifocal oedema, mass effect and ring-like contrast enhancement. A $2.5 \mathrm{~cm}$ enhancing nodule was seen anterior to the cystic lesion. There was no evidence of internal calcification. Gadolinium-enhanced magnetic resonance imaging (MRI) of the brain revealed an extra-axial lesion with mixed signal intensity and with solid cystic component in the right frontal lobe, measuring $1.7 \times 2.5 \times 3.3 \mathrm{~cm}$, with a large right paramedian cystic component measuring $3.8 \times 3.9 \times 4.4 \mathrm{~cm}$. The lesion had a broad base overlying the frontal convexity with subfalcine herniation. Heterogeneous postcontrast peripheral rim enhancement was noted (Fig. 1). The patient was referred to the department of neurosurgery, where she underwent right frontal craniotomy and Simpson's grade II removal of the right basifrontal tumour. Intraoperative findings included a dural-based firm relatively avascular extraaxial frontobasal tumour with attachment to the falx with amber-coloured fluid in the cystic component. There was no bony erosion and the tumour could be easily separated from the dura. The operative diagnosis was right basifrontal meningioma.

Microscopic examination of the solid component showed a malignant epithelial tumour arranged in nests and islands separated by fibrocollagenous septae. There was squamoid appearance of the tumour cells with palisading of basal cell nuclei. A pseudoglandular pattern was seen in places. Focal areas showed palisading of tumour cells. The cyst wall also showed foci of the same tumour. The various differential diagnoses considered were basaloid squamous cell carcinoma, meningioma, metastatic neuroendocrine carcinoma and glial tumour. Tumour cells were negative for glial fibrillary acidic protein (GFAP), vimentin, chromogranin and synaptophysin, thereby excluding the latter three possibilities. Immunopositivity against pan-cytokeratin, epithelial membrane antigen (EMA), 34 $3 \mathrm{E} 12$ and $\mathrm{p} 63$ antibodies supported the diagnosis of basaloid squamous cell carcinoma (Fig. 2). Thorough otorhinolaryngological examination including panendoscopy showed no evidence of disease. A whole body 18 F-FDG positron emission tomography (PET)-CT scan, performed to rule out any other primary site of disease, showed uptake only in the intracranial lesion (Fig. 3). The final impression was primary intracranial basaloid squamous cell carcinoma. Subsequently, the patient underwent postoperative radiation $60 \mathrm{~Gy}$ in 30 fractions over 6 weeks because of subtotal resection of the tumour. Radiation was planned by three-dimensional conformal technique (3DCRT) in the Eclipse treatment planning system (version 6.5) with two non-coplanar fields (right lateral skull and vertex) and $6 \mathrm{MV}$ photon beams. Radiation was delivered in 2 phases - initially $50 \mathrm{~Gy}$ in 25 fractions over 5 weeks followed by a cone-down boost of $10 \mathrm{~Gy}$ in 5 fractions over 1 week. The patient tolerated treatment well with no major toxicity or unplanned break. Contrast-enhanced CT scan of the brain performed 6 and 18 months after the completion of treatment showed no evidence of residuum or recurrence. At the last follow-up, two years after the initial diagnosis, the patient was found to be neurologically intact with no clinical evidence of disease.

\section{Discussion}

Intracranial squamous cell carcinoma may arise as metastatic spread from other squamous cell neoplasms or direct invasion from head and neck squamous cell carcinoma. Primary intracranial squamous cell carcino$\mathrm{ma}$ (PISCC) is a rarity. The majority of PISCCs have been found to arise by malignant transformation of a dermoid or epidermoid cyst [1-4]. Intracranial squamous cell carcinoma arising de novo is extremely rare and only four such cases have been reported in the available literature (Table 1).

Over the years, it has been postulated that the PISCC occurs by malignant transformation of a pre-existing epidermoid or dermoid cyst. The potential mechanisms include a chronic inflammatory response due to cystic rupture or subtotal resection of the cyst wall [1,4-6]. Cranial radiation has been associated with the development of ISCC in treated cases of craniopharyngioma [7]. According to Garcia et al. [8], an intracranial squamous cell neoplasm is classified as PISCC only when it fulfils all of the following criteria: 1) the tumour must be restricted to the intracranial, intradural compartment without invasion of, or extension beyond, the dura or cranial bones; 2) there must be no extension or invasion through intracranial orifices; 3 ) there must be no communication or connection with the middle ear, air sinuses or sella turcica; and 4) there must be no evidence of a nasopharyngeal tumour.

Primary intracranial squamous cell carcinoma peaks in the fourth to fifth decade. A slight male preponderance has been described in the literature [1]. The most common location is the cerebellopontine angle and most 

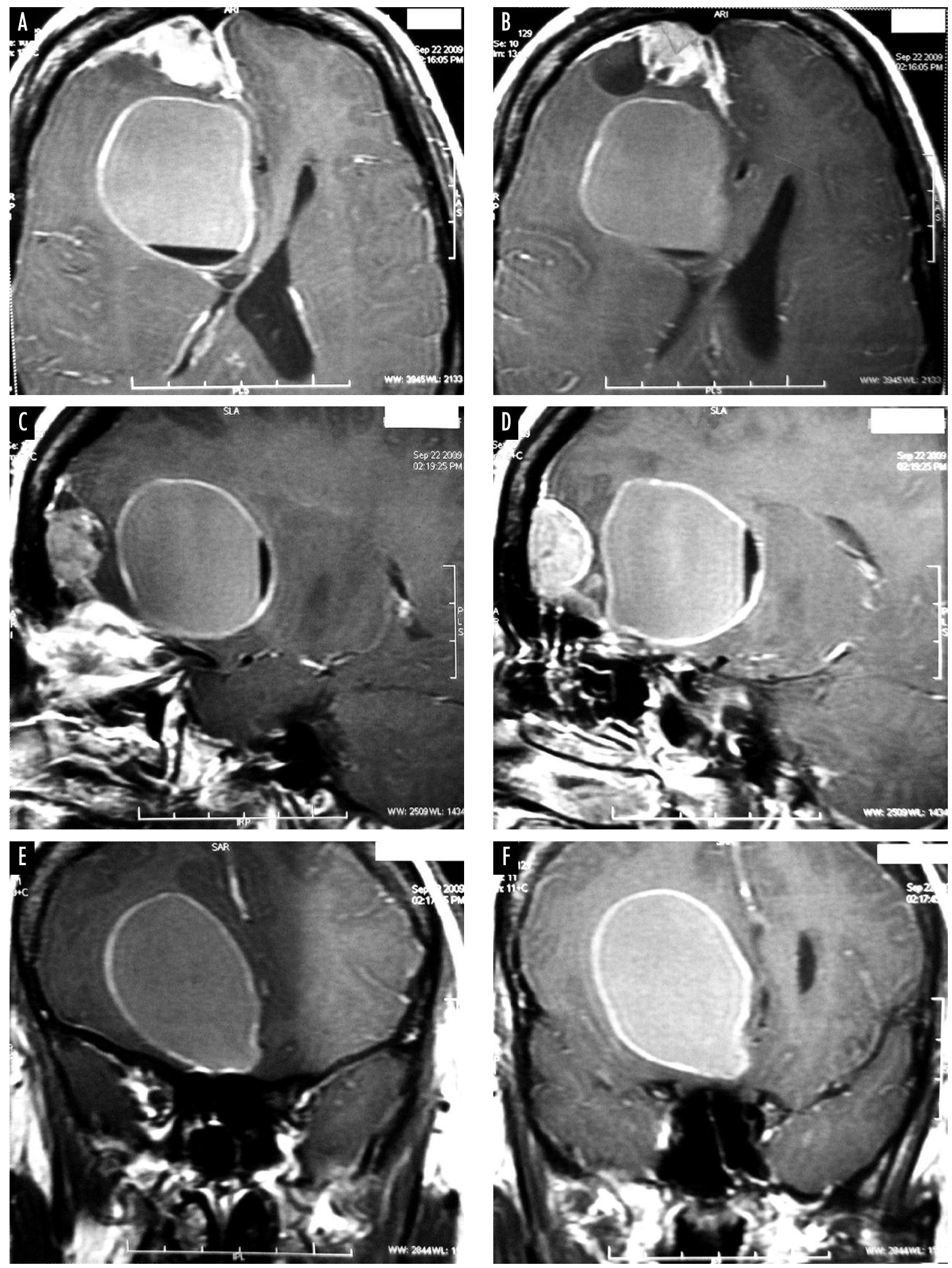

Fig. 1. Tl-weighted gadolinium-enhanced MRI of the brain (A - axial section; $\mathrm{B}$ - sagittal section; $\mathrm{C}$ - coronal section) reveals an extra-axial lesion with mixed signal intensity and with solid cystic component in the right frontal lobe measuring $1.7 \times 2.5 \times 3.3 \mathrm{~cm}$ with a large right paramedian cystic component measuring $3.8 \times 3.9 \times 4.4 \mathrm{~cm}$. The lesion has a broad base overlying the frontal convexity with subfalcine herniation. Heterogeneous post-contrast peripheral rim enhancement, midline shift and dilatation of the occipital horn of the left lateral ventricle are noted 

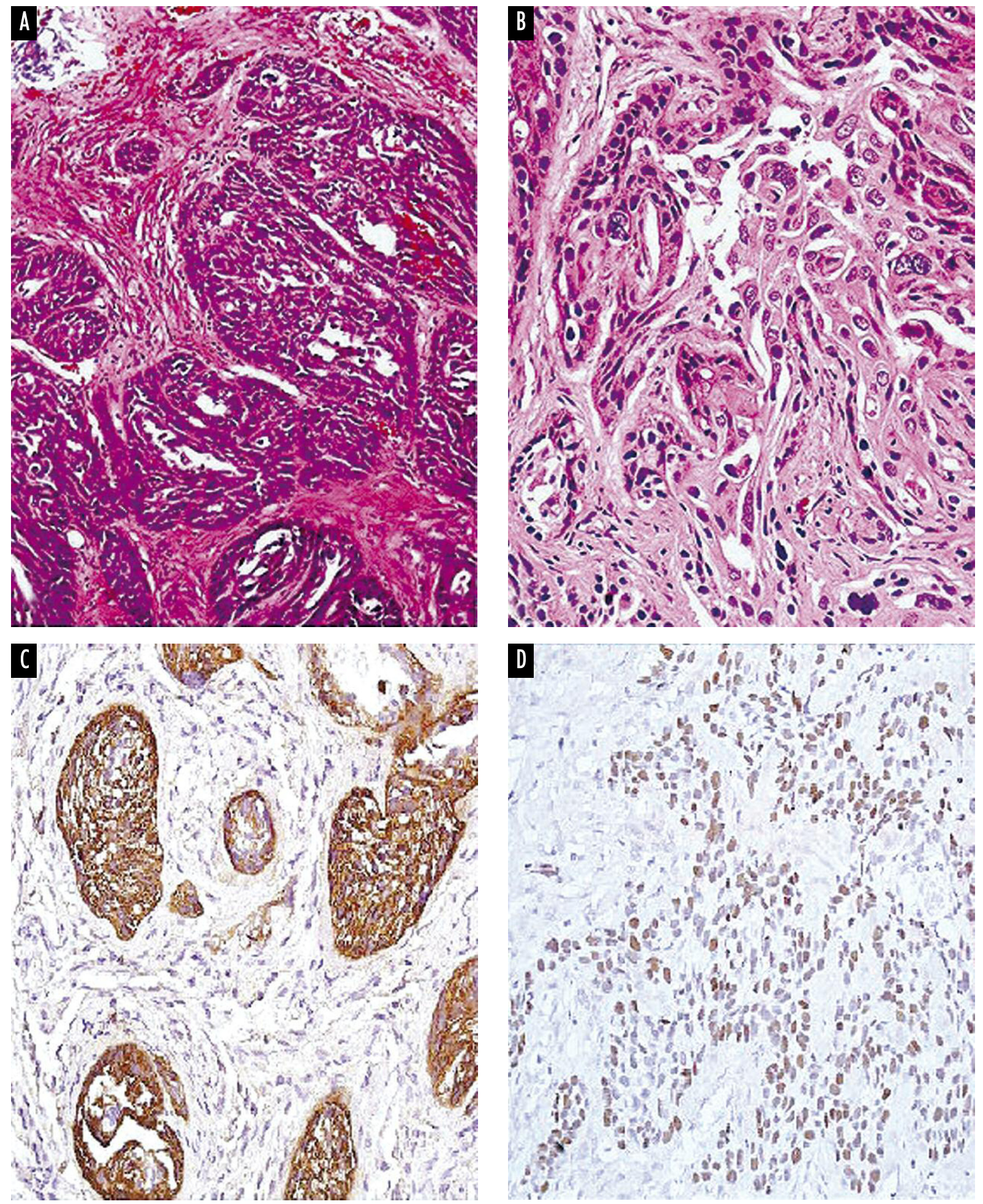

Fig. 2. (A) Tumour arranged in cribriform and pseudoglandular pattern along with palisading of tumour cells (H\&E, 200 $\times$ ). (B) Tumour with squamous differentiation (H\&E, 400 $\times$ ). Overall features are those of basaloid squamous cell carcinoma. (C) Immunopositivity against $34 \beta E 12(400 \times)$. (D) Immunopositivity against p63 $(400 \times)$ 


\section{A.}

2010
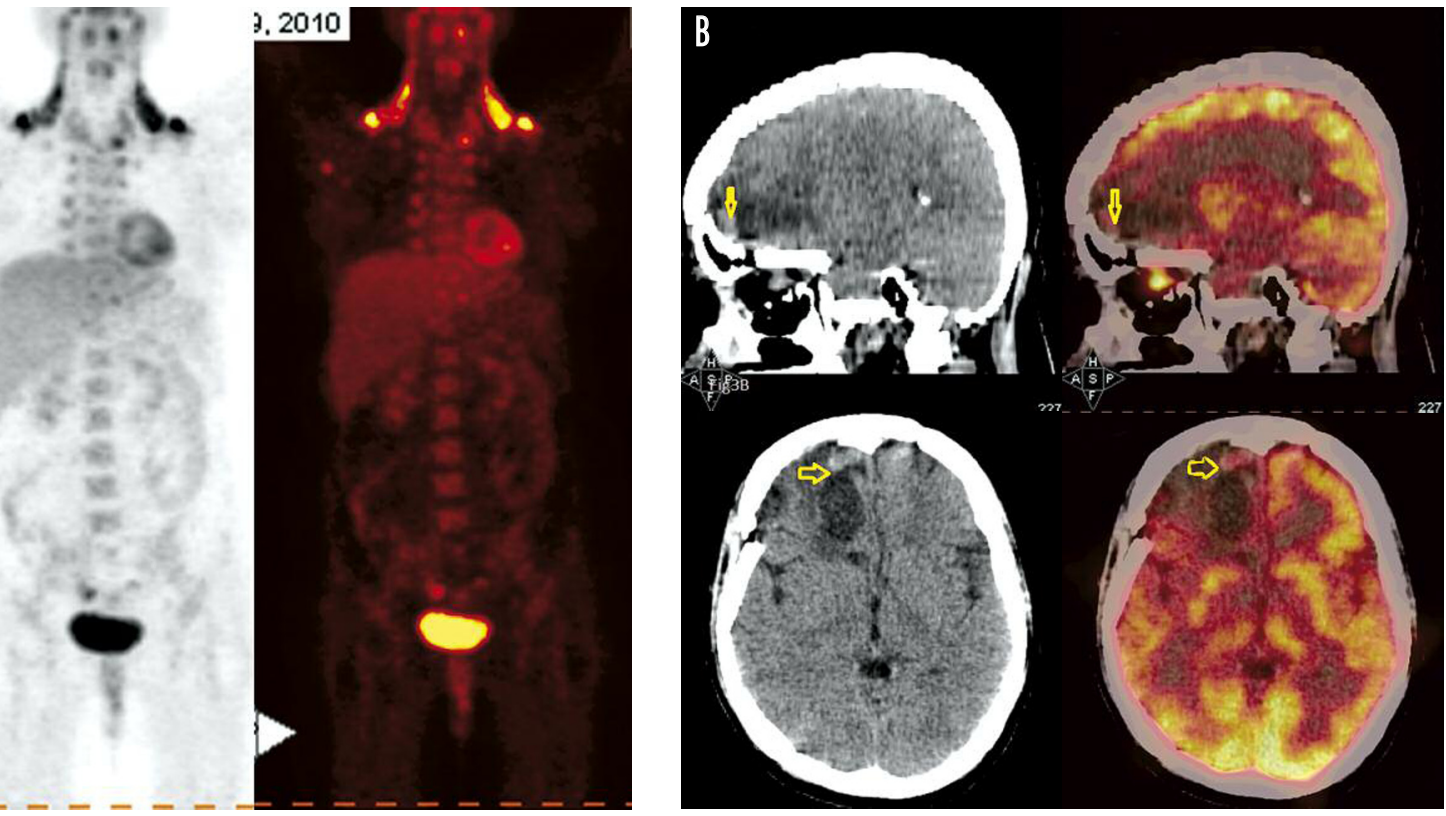

Fig. 3. (A) Whole body 18F-fluorodeoxyglucose (FDG) PET-CT scan shows no evidence of extracranial primary lesion. (B) Postoperative cavity in the right frontal lobe with residuum in the right basifrontal region showing mild FDG uptake (arrow)

Table 1. Cases of primary intracranial squamous cell carcinoma arising de novo - a summary

\begin{tabular}{|c|c|c|c|c|c|c|c|c|c|}
\hline No. & Author & $\begin{array}{c}\text { Age } \\
\text { [years]/ sex }\end{array}$ & $\begin{array}{l}\text { Tumour } \\
\text { location }\end{array}$ & Histopathology & Autopsy & $\begin{array}{l}\text { Tumour } \\
\text { origin }\end{array}$ & Treatment & Outcome & Survival \\
\hline 1 & $\begin{array}{l}\text { Nosaka } \\
\text { et al. [14] }\end{array}$ & $46 / \mathrm{M}$ & $\mathrm{CP}$ angle & $\mathrm{SCC}$ & $\mathrm{SCC}$ & Unknown & Surgery & Dead & $\begin{array}{l}\text { Overall survival } \\
-7 \text { months }\end{array}$ \\
\hline 2 & $\begin{array}{l}\text { Garcia } \\
\text { et al. }[8]\end{array}$ & $61 / \mathrm{M}$ & $\mathrm{CP}$ angle & $\mathrm{SCC}$ & $\mathrm{SCC}$ & Unknown & $\begin{array}{l}\text { Surgery } \rightarrow \\
\text { Post-op RT }\end{array}$ & Dead & $\begin{array}{l}\text { Overall survival } \\
-9 \text { months }\end{array}$ \\
\hline 3 & $\begin{array}{l}\text { Ebisudani } \\
\text { et al. [15] }\end{array}$ & 68/M & $\mathrm{CP}$ angle & $\mathrm{SCC}$ & $\mathrm{SCC}$ & Unknown & Surgery & Dead & $\begin{array}{l}\text { Overall survival } \\
-1 \text { month }\end{array}$ \\
\hline 4 & $\begin{array}{l}\text { Jain } \\
\text { et al. [12] }\end{array}$ & $5 / \mathrm{F}$ & $\begin{array}{l}\text { Right } \\
\text { temporal } \\
\text { lobe }\end{array}$ & $\begin{array}{c}\text { Poorly } \\
\text { differentiated } \\
\text { adenosquamous } \\
\text { carcinoma } \\
\text { (prominent SCC } \\
\text { component) }\end{array}$ & - & Unknown & $\begin{array}{l}\text { Surgery } \rightarrow \\
\mathrm{ChT} \rightarrow \mathrm{RT}\end{array}$ & $\begin{array}{l}\text { Local } \\
\text { recurrence }\end{array}$ & $\begin{array}{l}\text { Relapse-free } \\
\text { survival } \\
-10 \text { months }\end{array}$ \\
\hline 5 & $\begin{array}{l}\text { Present } \\
\text { case }\end{array}$ & $35 / \mathrm{F}$ & $\begin{array}{c}\text { Right } \\
\text { frontal lobe }\end{array}$ & $\begin{array}{l}\text { Basaloid } \\
\text { SCC }\end{array}$ & - & Unknown & $\begin{array}{l}\text { Surgery } \rightarrow \\
\text { Post-op RT }\end{array}$ & $\begin{array}{l}\text { Disease } \\
\text { free }\end{array}$ & $\begin{array}{l}\text { Overall survival } \\
-24 \text { months }\end{array}$ \\
\hline
\end{tabular}

$M$-male; F-female; $C P$-cerebellopontine; $S C C$-squamous cell carcinoma; ChT-chemotherapy; $R T$-radiotherapy

cases arise from pre-existing benign epidermoid or dermoid cysts $[1,4,9,10]$. Primary intracranial squamous cell carcinoma, because of its typical location, presents with features of cerebellopontine angle compression. Severe headache because of cerebrospinal fluid blockade is the most important presenting feature. Other neurological symptoms may be attributed to the tumour location and extension. As evidenced in other CNS malignancies, contrast enhanced MRI is the investigation of choice. Recent introduction of diffusion-weighted imaging (DWI) has been found to be extremely helpful in differentiating PISCC from other benign cysts. Benign cysts have very high signal intensity on DWI, whereas a highly malignant transformation will show low signal intensity on DWI and a ring-like enhancement on T1-weighted MRI after gadolinium 
injection $[4,11]$. CT without contrast enhancement can reveal calcifications in PISCC arising from remnants of epidermoid cysts [12].

Surgery remains the mainstay of treatment and has been used in the majority of cases. Location in close proximity to the brain stem or cerebellopontine angle, and adherence to brain parenchyma and cerebral blood vessels, often preclude a complete resection, however. Patients who undergo incomplete surgery merit further treatment in the form of postoperative radiotherapy. The existing literature shows that patients with PISCC have a very poor prognosis and median survival with surgery alone is around 9 months. Addition of adjuvant radiation may improve the outcome and prolong the median survival to as long as two years $[2,5]$. However, a consensus regarding optimal radiotherapy time-dosefractionation in PISCC is lacking because of the rarity of the disease.

Taking a cue from our clinical experience in postoperative radiotherapy in head and neck squamous cell carcinoma, we have prescribed a dose of $60 \mathrm{~Gy}$ in 30 fractions over a period of 6 weeks in the index patient. Intensity-modulated radiotherapy and stereotactic radiotherapy have been used as different methods of radiation delivery in PISCC. A few reports have emphasized the usefulness of gamma knife radiosurgery of postoperative residuum $[1,13]$. However, keeping in mind the various logistic constraints in a developing nation, we have used three-dimensional conformal radiotherapy. Clinical target volume (CTV) was defined as $1 \mathrm{~cm}$ uniform expansion encompassing the pre-operative tumour volume and perifocal oedema discerned on T1weighted post-contrast and T2-weighted MR images, respectively. A further isotropic expansion of $5 \mathrm{~mm}$ was given to the CTV to form the planning target volume to account for set-up error and intrafraction motion.

Chemotherapy has been used in some of the available reports in the form of intrathecal methotrexate. Murase et al. [1] used three courses of chemotherapy with the VMP-F regimen (vincristine, methotrexate, peplomycin and calcium folinate), a common regimen used in the management of cutaneous squamous cell carcinoma in Japan in the 1990s. Jain et al. [12] used four cycles of chemotherapy with cisplatin, VP-16, and ifosfamide followed by two cycles of dose-intensified cy clophosphamide and carboplatin with autologous stem cell rescue. But the response achieved was transient. Due to lack of conclusive evidence regarding the efficacy of chemotherapy in PISCC and minimal central nervous system penetration of the commonly used chemo- therapeutics in squamous cell neoplasm, we refrained from using chemotherapy in the index patient.

In the available reports on PISCC arising de novo $[8,12,14,15]$ (Table 1 ), the age at presentation varied from 5 to 68 years with a male to female ratio of $3: 2$. The most common location was the cerebellopontine angle. Surgery was the cornerstone of treatment, with post-operative radiotherapy and chemotherapy being used in 3 and 1 patient, respectively. Prognosis was uniformly poor with relentless disease progression within 6 months. The illustrative case is notable in being the first case of PISCC arising de novo in the frontal lobe, successfully treated with a combination of surgery and post-operative radiation with no evidence of disease 2 years after diagnosis.

In spite of its intricate anatomy, the human brain is essentially composed of neurons, the basic cells of the nervous system, and the neuroglial cells forming supportive tissue, all enclosed in three layers of connective tissue - the meninges. In a landscape which is so devoid of any presence of epithelium, evolution of PISCC is indeed intriguing. The majority of cases of PISCC arise by malignant transformation of dysembryogenetic lesions such as epidermoid and dermoid cysts, craniopharyngioma, etc. How can an intracranial squamous cell carcinoma arise de novo? The possibility of development from a pre-existing benign lesion, which has remained asymptomatic and undiagnosed until malignant progression, should be considered. In view of the frontobasal location of the tumour and proximity to the pa ranasal sinus, occult squamous cell carcinoma of the paranasal sinus with intracranial extension through the base of the skull is a distant possibility. However, it is extremely unlikely that an initially occult squamous cell carcinoma of the paranasal sinus with intracranial extension would remain silent for 2 years when only the intracranial part has been oncologically addressed.

\section{Conclusion}

Given the rarity of PISCC, the optimal treatment is largely undefined. Maximal safe resection followed by adjuvant radiotherapy is probably the best option. In spite of the poor prognosis associated with PISCC, such an approach might lead to a reasonable disease-free period, as seen in the illustrative case.

\section{Disclosure}

Authors report no conflict of interest. 


\section{References}

1. Murase S., Yamakawa H., Ohkuma A., et al. Primary intracranial squamous cell carcinoma. Neurol Med Chir (Tokyo) 1999; 39: 49-54.

2. Nishio S., Takeshita I., Morioka T., et al. Primary intracranial squamous cell carcinomas: report of two cases. Neurosurgery 1995; 37: 329-332.

3. Kobayashi T., Kuchiwaki H., Inao S., et al. A squamous cell carcinoma originated from intracranial dermoid cyst. Neurochirurgia 1993; 36: 26-29.

4. Kim M.S., Kim O.L. Primary intracranial squamous cell carcinoma in brainstem with a cerebellopontine angle epidermoid cyst. J Korean Neurosurg Soc 2008; 44: 401-404.

5. Hamlat A., Hua Z.F., Saikali S., et al. Malignant transformation of intracranial epidermoid cyst with leptomeningeal carcinomatosis: case report. Acta Neurol Belg 2003; 103: 221-224.

6. Abramson R.C., Morawetz R.B., Schlitt M. Multiple complications from an intracranial epidermoid cyst: case report and literature review. Neurosurgery 1989; 24: 574-578.

7. Kristopaitis T., Thomas C., Petruzzelli G.J., et al. Malignant craniopharyngioma. Arch Pathol Lab Med 2000; 124: 1356-1360.

8. Garcia C.A., McGarry P.A., Rodriguez F. Primary intracranial squamous cell carcinoma of the right cerebellopontine angle. J Neurosurg 1981; 54: 824-828.

9. Guan L.M., Qi X.X., Zhang J.R., et al. Intracranial squamous cell carcinoma developing in remnant of an epidermoid cyst: case report and literature review. Chin Med J (Engl) 2004; 117: 1880-1883.

10. Tamura K., Aoyagi M., Wakimoto H., et al. Malignant transformation eight years after removal of a benign epidermoid cyst: a case report. J Neurooncol 2006; 79: 67-72.

11. Nawashiro H., Higo R., Tokumaru A.M., et al. Diffusionweighted MRI of an intracranial epidermoid with malignant transformation. Neuroradiology 2001; 43: 891.

12. Jain R., Gujar S., McKeever P., et al. Imaging findings associated with childhood primary intracranial squamous cell carcinoma. Am J Neuroradiol 2003; 24: 109-111.

13. Mori Y., Suzuki Y., Tanasawa J., et al. A case report of epi dermoid carcinoma in cerebellopontine angle. No Shinkei Geka 1995; 23: 905-909.

14. Nosaka Y., Nagao S., Tabuchi K., et al. Primary intracranial epidermoid carcinoma. J Neurosurg 1979; 50: 830-833.

15. Ebisudani D., Hamazaki F., Oka H., et al. An autopsy case of primary intracranial squamous cell carcinoma. No Shinkei Geka 1990; 18: 193-198. 